\title{
Peningkatan Kompetensi Guru Pendidikan Kewarganegaraan (PKn) Melalui Supervisi Kelas
}

\author{
Hasyim \\ (Sekolah Binaan) SMP Negeri 4 Tapung \\ Dinas Pendidikan Kepemudaan Dan Olah Raga \\ Kabupaten Kampar \\ has4cyim@gmail.com
}

\begin{abstract}
Abstrak
Tujuan penelitian tindakan ini untuk mengetahui kompetensi guru Pendidikan Kewarganegaraan (PKn) di SMP Negeri 4 Tapung melalui supervisi kelas. Tempat Penelitian di SMP Negeri 4 Tapung Jl. Sekolah No. 01 Pantai Cermin, Kabupaten Kampar.Dimulai bulan September sampai dengan Nopember 2017.Subjek Penelitian ini adalah Guru Pendidikan Kewarganegaraan (PKn) kelas VIII.2 SMP Negeri 4 Tapung. Analisis data dilakukan secara deskriptif komparatif yang bertujuan untuk membandingkan kondisi sebelum dan sesudah diadakan tindakan perbaikan pembelajaran.Tahapan dalam tindakan menganalisis data meliputi reduksi data, penyajian data, dan penarikan kesimpulan. Sesuai dengan rancangan penelitian maka prosedur penelitian ini melalui 2 siklus, sebagaimana dijelaskan berikut ini :1. Tahap Perencanaan (Planning),2. Tahap Pelakasanaan (Acting),3. Tahap Pengamatan (Observing),4. Tahap Refleksi (reflecting).Hasil penelitian menunjukkan bahwa terdapat supervise kelas pada guru mata pelajaran Pendidikan Kewarganegaraan $(\mathrm{PKn})$ diperoleh pada Pra siklus mendapat nilai rata-rata 30 (prosentase 50\%) kriteria Cukup,siklus I mendapat nilai rata-rata 55 (prosentase75\%) criteria baik,siklus II meningkat menjadi 75 (prosentase 95\%) kriteria sangat baik,siklus II sudah mencapai indikator yang diharapkan.Dalam hasil penelitian yang telah dilakukan ini disimpulkan bahwa kompetensi guru dalam proses belajar mengajar dengan nilai rata-rata pra siklus yaitu sebesar 30 (prosentase 50\%) kriteria Cukup dan untuk siklus I sebesar 55 (prosentase 75\%) criteria baik. Dan siklus II sebesar 75 (prosentase 95\%) kriteria sangat baik.Dengan demikian Supervisi kelas dapat meningkatkan kompetensi guru dalam proses belajar mengajar.
\end{abstract}

Kata Kunci : Kompetensi guru, Pendidikan Kewarganegaraan (PKn), supervisi kelas.

\section{PENDAHULUAN}

Keberhasilan suatu proses pembelajaran tidak terlepas dari peran guru dalam mengelola proses pembelajaran di kelas. UU No. 20 Tahun 2003 Tentang SISDIKNAS menyatakan bahwa Pendidikan adalah usaha sadar dan terencana untuk mewujudkan suasana belajar dan proses pembelajaran agar peserta didik secara aktif mengembangkan potensi dirinya untuk memiliki kekuatan spritual keagamaan, pengendalian diri, kepribadian, kecerdasan, ahlak mulia, serta ketrampilan yang diperlukan dirinya, masyarakat, bangsa dan Negara. Banyak guru yang mengalami masalah/ kesulitan dalam melaksanakan pembelajaran pada mata pelajaran yang diampunya. Kesulitan tersebut dapat disebabkan oleh karakteristik mata pelajaran sehingga sulit 
dipahami guru atau kesulitan dalam aspekaspek teknis metodologis sehingga bahan ajar kurang dipahami peserta didik.Hal ini dibuktikan saat peneliti mencoba supervise waktu guru mengajar yang belum sesuai dengan proses belajar mengajar di kelas. Dalam hasil penelitian yang telah dilakukan ini menunjukkan bahwa kompetensi guru dalam proses belajar mengajar mendapat nilai ratarata pra siklus sebesar 30 (prosentase 50\%) kriteria Cukup.

Dengan rendahnya nilai rata-rata tersebut, supervisi kelas yang dilakukan pengawas sekolah kepada guru merupakan salah satu solusi/upaya membantu guru untuk mengatasi masalah yang dialaminya dalam rangka memperbaiki kualitas pembelajaran.Supervisi kelas adalah perbaikan pengajaran dengan hubungan yang intens berlanjut dan matang antara supervisor dan guru searah dengan perbaikan praktek profesional guru yang dapat menjamin kualitas pelayanan belajar secara berkelanjutan dan konsisten. Supervisi kelas memiliki karakteristik atau fokus antara lain, merubah cara mengajar serta didasarkan atas bukti pengamatan.

Berdasarkan uraian-uraian di atas, Peneliti menganggap pentingnya melakukan suatu

penelitian dengan membuat perbaikan pengajaran melalui penelitian tindakan sekolah dengan supervise kelas untuk meningkatkan kompetensi guru dalam proses belajar mengajar khususnya dalam belajar Pendidikan Kewarganegaraan, dengan mengangkat sebuah judul penelitian "Peningkatan Kompetensi Guru Pendidikan Kewarganegaraan (PKn) Melalui Supervisi Kelas".

\section{Identifikasi Masalah}

Berdasarkan latar belakang maka dapat diidentifikasi masalah dalam penelitian ini adalah sebagai berikut:

Rendahnya nilai kompetensi guru dalam proses belajar mengajar Pendidikan Kewarganegaraan.

\section{Rumusan Masalah}

Berdasarkan batasan masalah di atas, dapat dirumuskan masalah yang akan diteliti yaitu: "Apakah melalui Supervisi Kelas dapat meningkatkan kompetensi guru Pendidikan Kewarganegaraan (PKn) di SMP Negeri 4 Tapung?”.

\section{Tujuan Penelitian}

Tujuan penelitian tindakan ini untuk mengetahui :Kompetensi guru Pendidikan Kewarganegaraan (PKn) di SMP Negeri 4 Tapung melalui supervisi kelas.

\section{Manfaat Penelitian}

\section{Bagi Siswa}

Melalui penelitian tindakan ini diharapkan dapat meningkatkan partisipasi belajar dalam proses pembelajaran.

\section{Bagi guru}

Melalui penelitian tindakan ini diharapkan bermanfaat dalam meningkatkan kompetensi guru dalam mengatasi masalah pembelajaran dan pendidikan di dalam dan di luar kelas.

\section{Bagi Kepala Sekolah.}

Hasil PTK ini dapat menjadi masukan dalam penetapan kebijakan sekolah dalam rangka meningkatkan manajemen peningkatan mutu pendidikan di satuan pendidikannya.

\section{Bagi Peneliti}

Hasil Penelitian Tindakan Sekolah (PTS) ini dapat menjadi bahan refleksi untuk melakukan Penelitian Tindakan Sekolah (PTS) lebih lanjut pada setting kelas, lokasi, waktu dan subyek yang berbeda.

\section{KAJIAN TEORI}

\section{Pengertian Kompetensi Guru}

Kompetensi

Menurut UU No.14 tahun 2005 tentang Guru dan Dosen Pasal 1 Ayat 10, disebutkan: 
Kompetensi adalah seperangkat pengetahuan, ketrampilan, dan perilaku yang harus dimiliki, dihayati, dan dikuasai oleh guru atau dosen dalam melaksanakan tugas keprofesionalan.

Kompetensi dikategorikan mulai dari tingkat sederhana atau dasar hingga lebih sulit atau kompleks yang pada gilirannya akan berhubungan dengan proses penyusunan bahan atau pengalaman belajar, yang lazimnya terdiri dari:

1.penguasaan minimal kompetensi dasar.

2.praktik kompetensi dasar.

3.penambahan, penyempurnaan, atau pengembangan terhadap kompetensi atau keterampilan.

\section{Guru}

Guru, dalam Kamus Besar Bahasa Indonesia (KBBI) berarti seseorang yang memiliki profesi mengajar.

Guru adalah profesi yang ditandai dengan dimilikinya suatu kompetensi, guru yang berkompetensi adalah seorang yang memiliki ketrampilan serta kemampuan sebagai guru dalam melaksanakan tugasnya.

Kompetensi guru merupakan suatu ukuran yang ditetapkan atau dipersyaratkan dalam bentuk penguasaan pengetahuan dan perilaku perbuatan bagi seorang guru agar berkelayakan untuk menduduki jabatan fungsional sesuai dengan bidang tugas, kualifikasi, dan jenjang pendidikan.

Kompetensi guru merupakan perpaduan antara kemampuan personal, keilmuan, teknologi, sosial, dan spiritual yang secara kaffah membentuk kompetensi dasar profesi guru, yang mencakup penguasaan materi, pemahaman terhadap peserta didik, pembelajaran yang mendidik, pengembangan pribadi dan profesionalitas.

\section{Pengertian Pendidikan Kewarganegaraan (PKn)}

Pendidikan Kewarganegaraan merupakan mata pelajaran yang memfokuskan pembentukan warga negara yang dapat memahami \& bisa melaksanakan hak-hak serta kewajiban untuk menjadi warga negara Indonesia yang cerdas, terampil, \& berkarakter yang di amanatkan oleh Pancasila \& UUD 1945 (Depdiknas, 2006).

Pendidikan kewarganegaraan dapat diartikan sebagai penyiapan generasi muda dalam hal ini pelajar (siswa) untuk menjadi seorang warga negara yang mempunyai pengetahuan, kecakapan, \& nilai-nilai yang di perlukan untuk bisa berpartisipasi aktif dalam masyarakatnya (Samsuri, 2011).

\section{Tujuan Pendidikan Kewarganegaraan (PKn)}

Tujuan utama pendidikan kewarganegaraan yaitu untuk menumbuhkan wawasan dan kesadaran bernegara, sikap serta perilaku yang cinta tanah air dan bersendiakan kebudayaan bangsa, wawasan nusantara, serta ketahanan nasional dalam diri para calon penerus bangsa yang sedang menkaji dan akan menguasai ilmu pengetahuan dan teknologi serta seni.

Tujuan lain pendidikan kewarganegaraan yaitu untuk meningkatkan kualitas manusia indonesua yang berbudi luhur, berkepribadian, mandiri, maju, tangguh, profesional, bertanggung jawab, dan produktif serta sehat jasmani dan rohani.

\section{Pengertian Supervisi Kelas}

Supervisi kelas adalah serangkaian kegiatan yang akan dilakukan oleh pengawas untuk mengawasi tentang : setumpuk pembuatan administrasi kelas, akan diawasi dan dilihat kelemahan-kelemahannya selama mengajar, setelah itu akan menerima banyak nasehat yang berkaitan dengan tugas mengajar maupun perilaku guru pada umumnya.

\section{METODE}

Tempat Penelitian

Di SMP Negeri 4 Tapung Jl. Sekolah No. 01

Pantai Cermin, Kabupaten Kampar. 


\section{Waktu Penelitian}

Dimulai bulan September sampai dengan Nopember 2017.

\section{Subjek Penelitian}

Guru Pendidikan Kewarganegaraan (PKn) kelas VIII.2 SMP Negeri 4 Tapung.

\section{Sumber Data}

Sumber data penelitian adalah data primer yang diperoleh melalui wawancara, observasi dan supervisi kelas pada Guru PKn kelas VIII.2

\section{Teknik Pengumpulan Data}

Dalam PTS ini pengumpulan data dilakukan dengan teknik:

a. Supervisi, yaitu untuk memperoleh data secara langsung dari responden.

b. Observasi, yaitu untuk cross check data yang dikumpulkan dari instrument kegiatan belajar mengajar, tentang sikap dan perilaku guru selama kegiatan sehingga diharapkan mendapatkan data yang akurat.

c. Wawancara, yaitu melengkapi data yang diperoleh sebelum dan sesudah supervisi kelas.

\section{Validitas Data}

Untuk memperoleh data yang valid peneliti melalukan validasi data yang diperoleh dari supervise, observasi dan wawancara.

\section{Analisis Data}

Analisis data dilakukan secara deskriptif komparatif yang bertujuan untuk membandingkan kondisi sebelum dan sesudah diadakan tindakan perbaikan pembelajaran. Tahapan dalam tindakan menganalisis data meliputi reduksi data, penyajian data, dan penarikan kesimpulan.

\section{Indikator Kinerja}

Penelitian ini dianggap berhasil jika telah memenuhi indikator kinerja berikut:
Kompetensi guru dalam proses belajar mengajar sudah mencapai nilai 61-80 atau 81\%-100\% dengan kriteria sangat baik.

\begin{tabular}{|l|l|l|}
\multicolumn{3}{c}{ Kriteria Skor PBM guru : } \\
\hline Keterangan: & Rentang & Kriteria \\
\hline 1. Jika pernyataan dilakukan guru dengan kurang sesuai & $0-20$ & Kurang \\
\hline 2. Jika pernyataan dilakukan guru dengan cukup & $21-40$ & Cukup \\
\hline 3. Jika pernyataan dilakukan guru dengan baik & $41-60$ & Baik \\
\hline 4. Jika pernyataan dilakukan guru dengan sangat baik & $61-80$ & Sangat Baik \\
\hline
\end{tabular}

\section{Prosedur Penelitian}

Prosedur penelitian tindakan sekolah dilakukan secara bertahap mulai dari kegiatan awal (pra siklus), pelaksanaan tindakan siklus pertama dan siklus ke dua.

Sesuai dengan rancangan penelitian maka prosedur penelitian ini melalui 2 siklus, sebagaimana dijelaskan berikut ini :

1. Tahap Perencanaan (Planning)

2. Tahap Pelakasanaan (Acting)

3. Tahap Pengamatan (Observing)

4. Tahap Refleksi (reflecting)

\section{HASIL DAN PEMBAHASAN \\ Hasil}

Hasil penelitian menunjukkan bahwa terdapat supervise kelas pada guru mata pelajaran Pendidikan Kewarganegaraan (PKn) diperoleh pada Pra siklus mendapat nilai rata-rata 30 (prosentase 50\%) kriteria Cukup,siklus I mendapat nilai rata-rata 55 (prosentase $75 \%$ ) criteria baik, siklus II meningkat menjadi 75 (prosentase 95\%) kriteria sangat baik, siklus II sudah mencapai indikator yang diharapkan. Jadi penelitian sudah dihentikan.

Hasil pengamatan pada pra siklus,siklus I,siklus II dapat dilihat dalam daftar nilai dan grafik di bawah ini:

\begin{tabular}{|c|c|c|c|}
\hline KEGIATAN & JUMLAH & PROSENTASE & KRITERIA \\
\hline PRA SIKLUS & 30 & $50 \%$ & CUKUP \\
\hline SIKLUS I & 55 & $75 \%$ & BAIK \\
\hline SKLLUS II & 75 & $95 \%$ & SANGAT BAIK \\
\hline
\end{tabular}




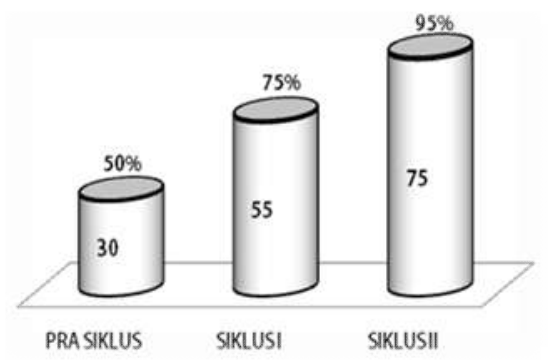

Hal ini berarti supervise kelas pada guru mata pelajaran Pendidikan Kewarganegaraan (PKn) akan semakin meningkat apabila proses belajar mengajar diterapkan secara baik.

\section{SIMPULAN DAN SARAN}

\section{Simpulan}

Dalam hasil penelitian yang telah dilakukan ini disimpulkan bahwa kompetensi guru dalam proses belajar mengajar dengan nilai rata-rata pra siklus yaitu sebesar 30 (prosentase 50\%) kriteria Cukup dan untuk siklus I sebesar 55 (prosentase $75 \%$ ) criteria baik. Dan siklus II sebesar 75 (prosentase 95\%) kriteria sangat baik. Dengan demikian Supervisi kelas dapat meningkatkan kompetensi guru dalam proses belajar mengajar.

\section{Saran}

Berdasarkan dari hasil dalam penelitian ini maka dapat penulis sarankan:

Terhadap Guru:

Pada suatu proses pembelajaran hendaknya guru menggunakan metode/pendekatan yang sesuai dengan materi yang akan diajarkan dan melakukan analisis materi pelajaran yang akan disampaikan serta berperan dalam mendampingi siswa ketika proses pembelajaran berlangsung untuk meningkatkan mutu pendidikan.

Terhadap Kepala Sekolah.

Diharapkan kepala sekolah dapat memfasilitasi dan dapat mendorong guru-guru untuk menyampaikan secara terbuka hambatanhambatan dan kesulitan-kesulitan yang dialami dalam proses pembelajaran untuk ditindaklanjuti dalam suatu tindakan sekolah.

\section{DAFTAR PUSTAKA}

Arikunto, S. (1998). Prosedur Penelitian. Jakarta: Rinneka Cipta

Jejen Musfah. (2011). Peningkatan Kompetensi Guru, Jakarta: Kencana, Cet 1.

Sugiyono. 2009. Metode Penelitian Kuantitatif, kualitatif, dan $R \& D$. Bandung: Alfabeta.

Wagiran. (2014). Metodologi Penelitian Pendidikn. Teori \& Implementasi. Yogyakarta: Depublish 